\title{
Propagation of Flood Wave in River and Construction Riverbanks - Example of River Velika Morava
}

\author{
Aleksandra Rajcevic \\ Faculty of Civil Engineering, University of Belgrade, Belgrade, Serbia \\ Email address: \\ aleksandra_rt@mts.rs \\ To cite this article: \\ Aleksandra Rajcevic. Propagation of Flood Wave in River and Construction Riverbanks - Example of River Velika Morava. American \\ Journal of Applied Mathematics. Vol. 8, No. 2, 2020, pp. 46-50. doi: 10.11648/j.ajam.20200802.11
}

Received: December 26, 2019; Accepted: February 3, 2020; Published: February 13, 2020

\begin{abstract}
In hydraulics area there is an open space for apply of numerical methods, instead of frequently used empirical formulas. At first place numerical methods may be used in river flow hydraulics and ground water flow. Application of numerical methods is given enough correct results and prediction for all parameters in river flow, that is presented in this paper. Natural phenomenon of flood wave is researched and original numerical method is shown, having calculation of water depth as primary goal. There are different amount of flooding in river in correspondence with event frequency which are monitored through numerical calculation and measuring. Numerical calculation of water depth in huge amount of flooding is important for defined defense areas. In this paper is researched flood wave in river Velika Morava, propagated from city Naissus to measuring station Bagrdan, continuing to city Smederevo where is merged with Danube. Flooding is unsteady flow with dominant part of kinetic energy. Propagation of flood wave is analyzed as plane problem and through numerical procedure are calculated values of water depth. Calculation results of propagated flood wave is treated with measured data water depth $\mathrm{H}$ and discharge Q. Presented calculated and measured data are compared and they have small differences, therefor results are acceptable as correct. Whole volume of flooded water in river is analyzed for calculation results correction and average cross section of flow is got.
\end{abstract}

Keywords: Numerical Methods, Flood Wave, Defense of Flood

\section{Introduction}

There is technical need to defense river sides of flooding as may be viewed in applied Water resources systems base [2], forming defended areas in which building objects is prohibited and construction sides are needed.

There are different amount of flooding in river in correspondence with event frequency, flooding on event period 10,50 or 100 years are monitored through numerical calculation and measuring. Numerical calculation of water depth (pick of hydro graph) in huge amount of flooding is important for defined defense areas.

In this article is considered flooding wave in river Velika Morava. River Velika Morava is considered from city Naissus to measuring station Bagrdan till city Smederevo where is merged with Danube. Entire length of considered river is about $100 \mathrm{~km}$. Water measuring station of Republic hydro meteorological service of Serbia named Bagrdan is placed at about $80 \mathrm{~km}$ from Danube, with ground level about $102.14 \mathrm{~m}$ and zero level of measuring wood $100.94 \mathrm{~m}$.
Measuring data that is used in numerical calculation is discharge $\mathrm{Q}\left(\mathrm{m}^{3} / \mathrm{s}\right)$ and for correction of calculation water depth in river $\mathrm{H}(\mathrm{m})$.

\section{Mathematical Formulation of Problem}

On two dimensional function is applied total differential, function of depth $(\mathrm{m})$ in river is presented unsteady two dimensional flow in river (plan problem):

$$
\mathrm{z}=\mathrm{f}(\mathrm{x}, \mathrm{t})-\text { river flow }
$$

$\mathrm{x}$ - stationary

$\mathrm{t}$ - time

$$
\begin{gathered}
\mathrm{h}=\mathrm{f}(\mathrm{x}, \mathrm{t})-\text { water depth in river }(\mathrm{m}) \\
\mathrm{h}(\mathrm{y})=\text { const. } \partial \mathrm{h} / \partial \mathrm{y}=0
\end{gathered}
$$

Numerical Procedure:

$$
\Delta \mathrm{h}=\partial \mathrm{h} / \partial \mathrm{x} \Delta \mathrm{x}+\partial \mathrm{h} / \partial \mathrm{t} \Delta \mathrm{t}
$$


Numerical method - A. RAJČEVIĆ [3]

$$
\mathrm{V}=\mathrm{h}_{\mathrm{av}} \Delta \mathrm{x}
$$

$$
\mathrm{V}=\left(\mathrm{h}_{\mathrm{i}}+\mathrm{h}_{\mathrm{i}+1}\right) / 2 \Delta \mathrm{x} \quad \mathrm{V} \text { - two dimensional volume value }
$$

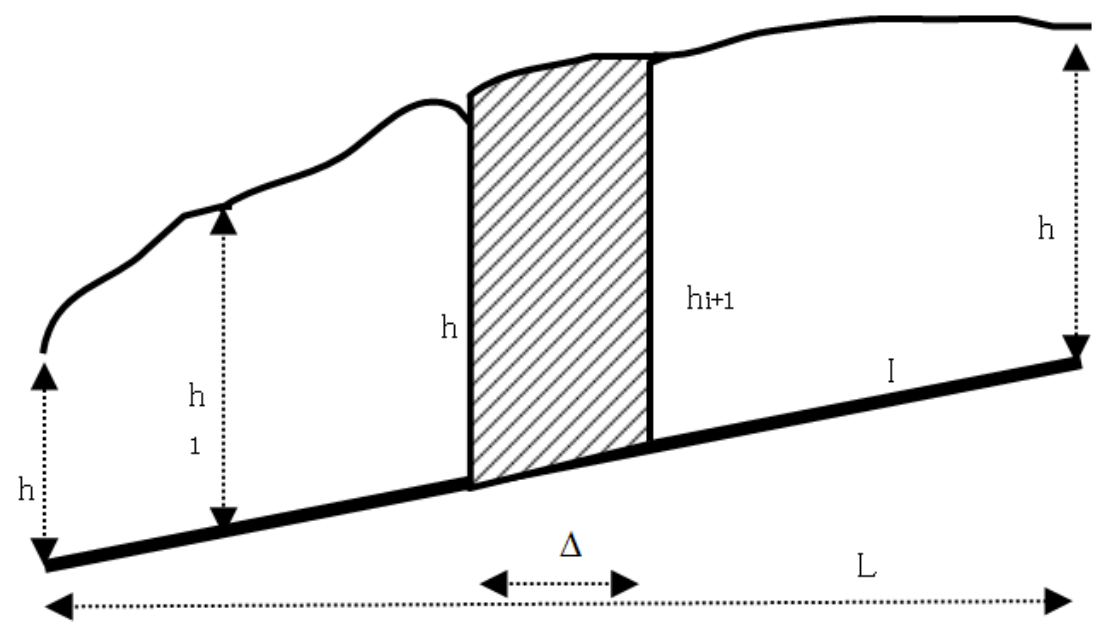

Figure 1. River flow.
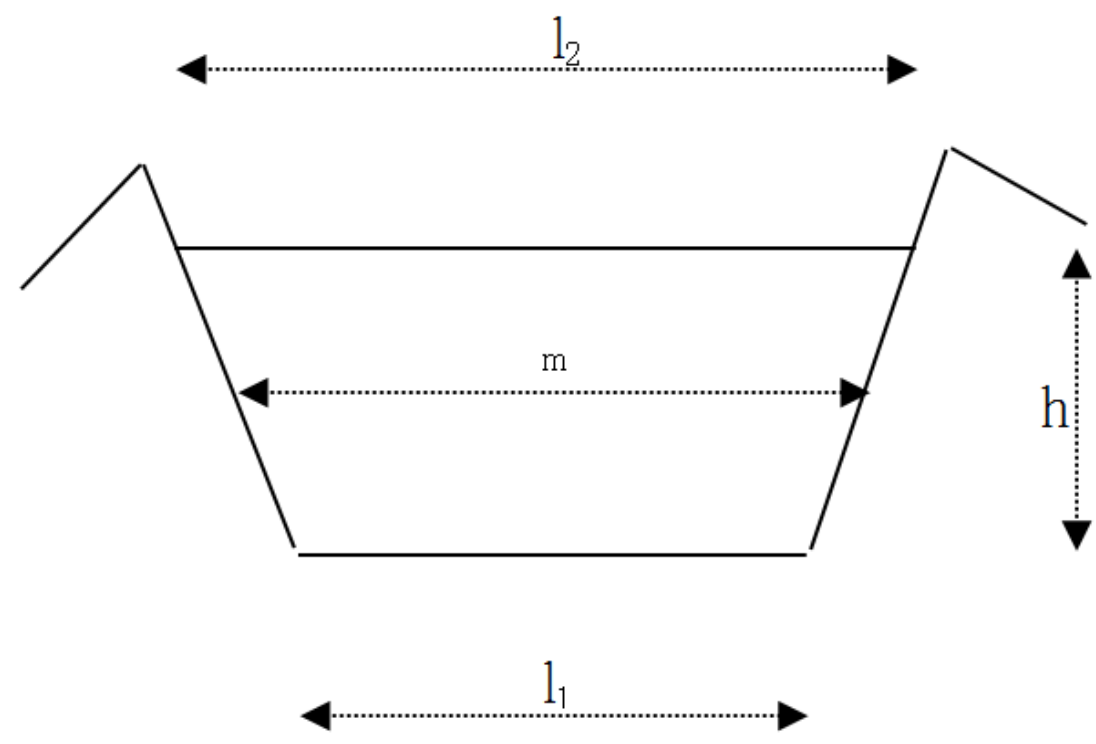

Figure 2. River basin-cross section.

$$
\begin{gathered}
\mathrm{h}_{\mathrm{av}}=\mathrm{V} / \Delta \mathrm{x} \\
\partial \mathrm{h} / \partial \mathrm{t}=\partial \mathrm{V} / \partial \mathrm{x} \partial \mathrm{t}=\partial q / \partial \mathrm{x} \\
\partial \mathrm{h} / \partial \mathrm{x}=\mathrm{I}
\end{gathered}
$$

I - river bottom slope (\%)

$\mathrm{V}-$ volume

$$
\begin{gathered}
\Delta \mathrm{h}=\partial \mathrm{h} / \partial \mathrm{x} \Delta \mathrm{x}+\partial \mathrm{V} / \partial \mathrm{x} \partial \mathrm{t} \Delta \mathrm{t} \\
\Delta \mathrm{h}=\partial \mathrm{h} / \partial \mathrm{x} \Delta \mathrm{x}+\partial \mathrm{q} / \partial \mathrm{x} \Delta \mathrm{t}
\end{gathered}
$$

$\Delta \mathrm{x}-$ distance step $(\mathrm{m})$

$\Delta \mathrm{t}$ - time step (s)

$q$ - discharge - plan problem $\left(\mathrm{m}^{2} / \mathrm{s}\right)$

Iterative Procedure:

$\mathrm{h}_{\mathrm{i}+1}-\mathrm{h}_{\mathrm{i}}=\left(\mathrm{I}_{\mathrm{i}+1}-\mathrm{I}_{\mathrm{i}}\right) \Delta \mathrm{x}+\left(q_{\mathrm{j}+1}-q_{\mathrm{j}}\right) /\left(\mathrm{x}_{\mathrm{i}+1}-\mathrm{x}_{\mathrm{i}}\right) \Delta \mathrm{t}$ $\mathrm{i}=1, \mathrm{n}-$ distance step count $\mathrm{j}=1, \mathrm{k}$ - time step count $\left(\mathrm{I}_{\mathrm{i}+1}-\mathrm{I}_{\mathrm{i}}\right) \Delta \mathrm{x}$ - steady part of equation $\left(q_{\mathrm{j}+1}-q_{\mathrm{j}}\right)\left(\mathrm{x}_{\mathrm{i}+1}-\mathrm{x}_{\mathrm{i}}\right) \Delta \mathrm{t}-$ unsteady part of equation

$$
q=\mathrm{Q} / \mathrm{m}
$$

$$
\mathrm{m}-\text { water table width }=\left(1_{1}+1_{2}\right) / 2
$$

Flood wave is researched in lowland, on about $100 \mathrm{~km}$ river length, considering that flood wave is propagated long distance. Depth time changes are calculated in downstream cross sections and it is possible calculated water depth in river upstream in the same time section. (Table 1)

For river flow is adopted trapezoid river basin and water depth is taken constant in cross section (y direction in river basin), having river flow as plane problem (3) (4).

Iterative procedure is counted with plane value of 
discharge $q\left(\mathrm{~m}^{2} / \mathrm{s}\right)$, which is taken into count involving middle line trapezoid river basin $\mathrm{m}$ (water table width), whole discharge is divided with value $\mathrm{m}$ (10) (11) (12).

Correction Procedure:

Correction procedure is analyzed whole volume of flood wave. Whole volume is divided with duration of flooding, so daily volume is calculated. After daily volume is divided with length of river with flooding wave propagation it is possible to contemplate average cross section during river flooding.

Whole volume of water in flooding wave:

$$
\begin{gathered}
\mathrm{V}_{\mathrm{t}}=\Sigma \mathrm{Q} * \Delta \mathrm{t} \mathrm{i}=1, \mathrm{n} \\
\mathrm{A}_{\text {average }}=\mathrm{V}_{\mathrm{t}} / \mathrm{L} / \mathrm{T} \mathrm{m}^{2} / \mathrm{km} / \text { day } \\
\mathrm{A}_{\mathrm{av}}=\mathrm{m}_{\mathrm{av}} \mathrm{h}_{\mathrm{av}}
\end{gathered}
$$

$A_{\text {average }}$ - average cross section $\left(\mathrm{m}^{2}\right)$

$\mathrm{L}$ - length of river with flooding wave propagation $(\mathrm{km})$

$$
\mathrm{T} \text { - duration of flooding (days) }
$$

\section{Results of Calculation}

Natural phenomenon of flooding in river is unsteady flow, problem is dealt as two dimensional equation flow (plan problem). Natural phenomenon of flooding is contemplated as river flow with dominant influence of kinetic energy.

Calculation results of propagated flooding wave are treated with measuring data water depth $\mathrm{H}(\mathrm{m})$ and discharge $\mathrm{Q}$ $\left(\mathrm{m}^{3} / \mathrm{s}\right)$ in river Velika Morava, on measuring station Bagrdan with level zero on water measuring board 100.94 (m) in period march april 1997.

Results of calculation are given by numerical procedure, in three time sections 12 hours, 24 hours and 36 hours from start of propagation flooding wave and they are compared with measured data. Presented calculated and measured data in following Table 1 have small differences.

Table 1. Results of calculation.

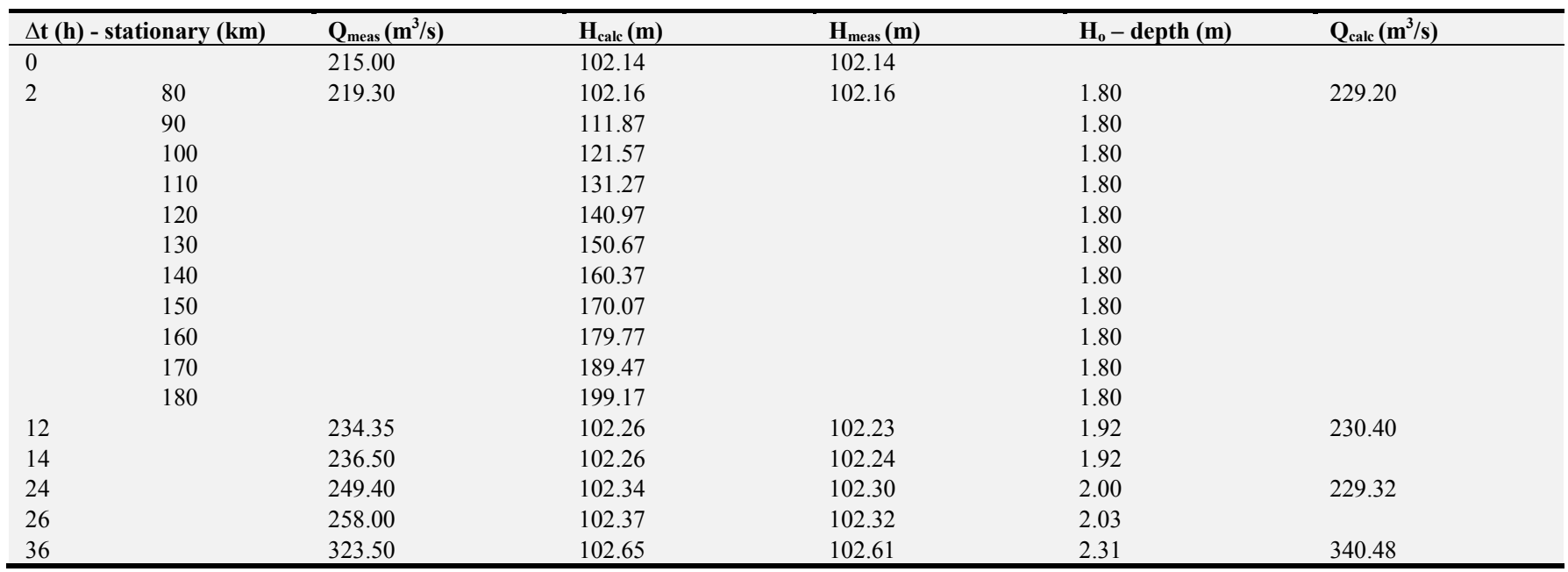

Correction of calculated results with measured data is used in modeling and is called model verification.

For numerical procedure are taken boundary conditions $[\mathrm{Q}(\mathrm{t}), \mathrm{H}(0)]$. First boundary condition are discharge data $\mathrm{Q}(\mathrm{t})$ - hydro graph (values) of flooding wave and the second is normal depth $\mathrm{H}(\mathrm{m})$ in steady flow. These were measured data $[4][5,6]$.

First step in numerical procedure is calculation of water depth $H(m)$ related with the time changes of discharge $Q(t)$. Second step is calculation of numerical value of discharge $\mathrm{Q}_{\text {calc }}(\mathrm{t})$ with assumed value of velocity $\mathrm{v}(\mathrm{m} / \mathrm{s})$ in river, that can be compared with measured discharge $\mathrm{Q}(\mathrm{t})$.

Duration of researched flood wave is 12.3 days. Maximum realized discharge is $\mathrm{Q}_{\max }=1202.3 \mathrm{~m}^{3} / \mathrm{s}$ and maximum realized depth is $\mathrm{h}_{\max }=5.06 \mathrm{~m}$.

Calculation:

time step $\Delta \mathrm{t}=2 \mathrm{~h}, \mathrm{t}_{1}=12 \mathrm{~h}$

stationary $\mathrm{x}_{1}=80 \mathrm{~km}, \Delta \mathrm{x}=10 \mathrm{~km}$

$\mathrm{H}_{2}-\mathrm{H}_{1}=\mathrm{I}_{12} \Delta \mathrm{x}+\Delta q / \Delta \mathrm{x} \Delta \mathrm{t}$

$\Delta \mathrm{h}=\Delta q_{1} / \Delta \mathrm{x} \Delta \mathrm{t}$

$\mathrm{Q}_{1}(\mathrm{t}=0)=215 \mathrm{~m}^{3} / \mathrm{s}$
$\mathrm{Q}_{2}(\mathrm{t}=12 \mathrm{~h})=234.35 \mathrm{~m}^{3} / \mathrm{s}$

$\Delta \mathrm{Q}=19.35 \mathrm{~m}^{3} / \mathrm{s}$

$\Delta \mathrm{Q}(\Delta \mathrm{t}=2 \mathrm{~h})=19.35 / 6=3.23 \mathrm{~m}^{3} / \mathrm{s}$

$\Delta q_{1}=3.23 / 120=0.0269 \mathrm{~m}^{2} / \mathrm{s}$

$\Delta \mathrm{h}(\Delta \mathrm{t}=2 \mathrm{~h})=0.0269 / 10000 * 2 * 3600=0.019 \mathrm{~m}$

$\Delta \mathrm{h}(\Delta \mathrm{t}=10 \mathrm{~h})=0.019 * 5=0.097 \mathrm{~m}$

$\Delta \mathrm{t}=2 \mathrm{~h}$

$\mathrm{H}_{1}=\mathrm{H}_{0}+\Delta \mathrm{h}$

$\mathrm{H}_{0}=102.14 \mathrm{~m}$

$\mathrm{H}_{1}=102.14+0.019=102.16 \mathrm{~m}$

$\mathrm{H}_{\text {bott }}=100.34 \mathrm{~m} \mathrm{~h}_{0}=1.80 \mathrm{~m}$

$\mathrm{t}_{1}=12 \mathrm{~h}$

$\mathrm{H}_{2}=\mathrm{H}_{1}+\Delta \mathrm{h}$

$\mathrm{H}_{2}=102.16+0.097=102.26 \mathrm{~m}$

$\mathrm{h}_{0}=1.92 \mathrm{~m}$

Calculated discharge - correction of discharge $\mathrm{Q}(\mathrm{t})$ :

$\mathrm{m}=120 \mathrm{~m}$

$\mathrm{Q}=\mathrm{v} * \mathrm{~A}=\mathrm{v} * \mathrm{~m} * \mathrm{~h}_{0}=1.0 \mathrm{~m} / \mathrm{s} * 120 \mathrm{~m} * 1.92 \mathrm{~m}=$ $230.40 \mathrm{~m}^{3} / \mathrm{s}$

Like it could be seen in presented Table 1 calculated and measured discharge $\mathrm{Q}_{\text {calc }}$ and $\mathrm{Q}_{\text {meas }}$ are compared, also 
calculated and measured depth in river $\mathrm{H}_{\text {calc }}$ and $\mathrm{H}_{\text {meas. }}$ With result comparison could be noticed that differences are between $(2-4) \mathrm{cm}$. So solid results of calculation are got mostly thanks to solid chosen cross section geometry.

For each time section in calculation it is possible to calculated river level upstream of calculation cross section (stationary), acquiring same increment of depth $\Delta \mathrm{h}$ having in mind natural river basin slope (adopted $\mathrm{I}=0.1 \%$ ).

Numerical method enabled enough accuracy calculation for $\Delta \mathrm{t}=12 \mathrm{~h}$. It is calculated average increment of depth for $\Delta \mathrm{t}=2 \mathrm{~h}$, after that same increment is calculated for $\Delta \mathrm{t}=12 \mathrm{~h}$ with good accuracy, as shown in presented example.

There is solid agreement calculated discharge with measured. Calculated discharge is taken into count with assumed velocity in river $\mathrm{v}=1 \mathrm{~m} / \mathrm{s}$ by experience. Assumed value is also water table width $\mathrm{m}=120 \mathrm{~m}$.

Correction Procedure:

Total volume of flooding wave during 12 days of flooding: $\mathrm{V}=798.59 * 10^{6} \mathrm{~m}^{3}$

$\mathrm{V}_{\text {day }}=798.59 * 10^{6} / 12.3$ days $=64.93 * 10^{6} \mathrm{~m}^{3} /$ day

Average cross section:

$\mathrm{L}=100 \mathrm{~km}$ - assumed length of river with flooding

$A_{\text {average }}=V_{\text {day }} / \mathrm{L}=64.93 * 10^{6} / 100 * 10^{3}=649.3 \mathrm{~m}^{2} /$ day

$\mathrm{A}_{\mathrm{av}}=\mathrm{m} * \mathrm{~h}_{\mathrm{av}}=185 * \mathrm{~h}_{\mathrm{av}}=649.30 \mathrm{~m}^{2}$

$\mathrm{h}_{\mathrm{av}}=649.3 / 185=3.51 \mathrm{~m}$

In correction procedure is calculated whole volume of water in flood wave $\mathrm{V}=798.59 * 10^{6} \mathrm{~m}^{3}$. Average depth in cross section river during flood wave is $\mathrm{h}=3.51 \mathrm{~m}$, while average water table width is $\mathrm{m}=185 \mathrm{~m}$.

Floodwave march aril 1997

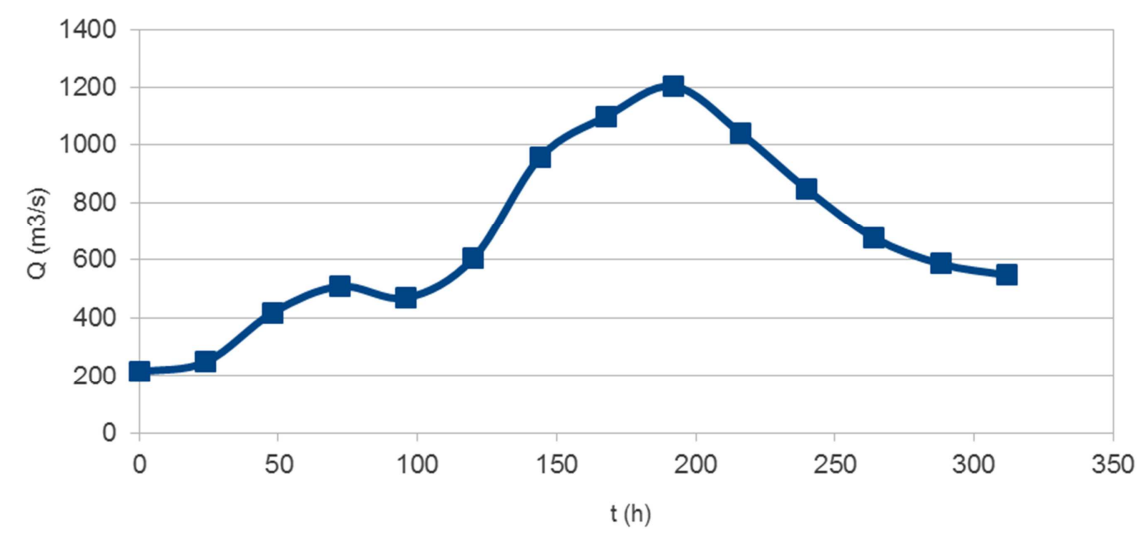

Figure 3. Hydro graph - Flooding wave discharge $Q\left(\mathrm{~m}^{3} / \mathrm{s}\right)$.

On Figure 3 is shown hydro graph of flooding wave in river Velika Morava in march april 1997. Also there are presented values of discharge Q $\left(\mathrm{m}^{3} / \mathrm{s}\right)$ during $312 \mathrm{~h}$ of flood wave.

\section{Conclusion}

In presented analysis can be concluded that numerical procedure is correct, that in practice there are solid agreement calculated and measured values of depth $\mathrm{H}(\mathrm{m})$, and results are acceptable as correct. Evaluated relative error of calculated depth is $\partial \approx 3 \%$.

Presented numerical method and numerical procedure are applied numerical mathematics without empirical formulas on river flow with good accuracy. Manning's formula usually applied on channel flow, on river flow cannot be considered truthful.

Good accordance measured and calculated values showed that in flow equation significant part has river flow kinetic energy in the case of extremely unsteady flow like flooding and that the influence of friction energy loss is neglected or significantly smaller. Flooding is natural phenomenon that may be considered like extremely unsteady flow in such cases $[7,8,11]$.
Showed numerical procedure can applied on flooding with different recurrence period and may calculated maximum value of water depth $\mathrm{H}(\mathrm{m})$, peak of hydro graphs and than may be taken defense consideration, building the river sides. Flood wave with return period $\mathrm{T}=100$ years are determinative for dimensioning and construction riverbanks and flood defense.

Using numerical procedure some of the used river flow values are assumed by the experience and are taken from the geographical map like water table width $(\mathrm{m})$, length of river flow with flooding $\mathrm{L}(\mathrm{km})$, velocity $\mathrm{v}(\mathrm{m} / \mathrm{s})$ in river and so on [13-15].

In numerical procedure measured values of discharge $Q$ $\left(\mathrm{m}^{3} / \mathrm{s}\right)$ with flooding have had return period $\mathrm{T}=50$ years with an assumption that a flooding is propagated on whole distance in lowland. Through correction procedure may calculated and compared distance of flooding $\mathrm{L}(\mathrm{km})$. Presented numerical method could be used for calculation depth changes in accumulations.

It is possible that if measured values of velocity $\mathrm{v}(\mathrm{m} / \mathrm{s})$ in river flow and length of river with flooding $\mathrm{L}(\mathrm{km})$ are disposable better accuracy of calculation will be reached. New and original numerical method presented in this paper have had large significance for this field of research. 


\section{References}

[1] A. Rajčević, Flood wave spreading in streams and riverbanks planning - flood wave modeling (Prostiranje poplavnog talasa $\mathrm{u}$ vodotoku i uređenje rečnih obala - modeliranje poplavnog talasa), Water and sanitary technique (Voda i sanitarna tehnika) 3/2013, Belgrade.

[2] Institute Jaroslav Černi, Water resources systems base (Vodoprivredna osnova), Belgrade, 2002.

[3] B. Jovanović and D. Radunović, Numerical methods (Numeričke metode), Mathematics faculty in Belgrade, 2003.

[4] Republic hydro meteorological service of Serbia, Measuring data.

[5] A. Rajčević, S. Djordjević, M. Ivetić and Č. Maksimović, An Approach to the Simulation of Street Flooding in the Modelling of Surcharged Flow in Storm Sewers, Proc. UDT '91 Conference, Dubrovnik, 1991., Elsevier.

[6] A. Rajčević, S. Djordjević, M. Ivetić and Č. Maksimović, Modelling of Surcharged Flow in Storm Sewers with Water Exchange Through The Inlet Openings, Hydrocomp '92 Conference, Budapest, 1992.

[7] G. Hajdin, Fluid Mechanics (Mehanika fluida), Gradjevinska knjiga, Faculty of Civil Engineering, University of Belgrade, 1983.

[8] G. Hajdin, Fluid Mechanics book II Introduction in hydraulics (Mehanika fluida knjiga druga Uvodjenje u hidrauliku), Faculty of Civil Engineering, University of Belgrade, 2002.

[9] Č. Maksimović, D. Obradović and M. Radojković,
Computational sanitary hydrotechnique (Računari $\mathrm{u}$ komunalnoj hidrotehnici), Gradjevinska knjiga, Belgrade, 1990.

[10] B. Djordjević, Water resources systems (Vodoprivredni sistemi), Naučna kjiga, Faculty of Civil Engineering, University of Belgrade, 1990.

[11] M. Boreli, Hydraulics (Hidraulika), Naučna knjiga, Faculty of Civil Engineering, University of Belgrade, 1984.

[12] A. Rajčević, S. Djordjević, M. Drašković and Č. Maksimović, UDM - Italiana (Urban drainage modelling Italiana), Institute of Hydrotechnics, Faculty of Civil Engineering, University of Belgrade, 1993. (unpublished).

[13] A. Rajčević, Hydrology seminar paper, Faculty of Civil Engineering, University of Belgrade, 1989. (unpublished).

[14] A. Rajčević, Exploring water powers seminar paper, Faculty of Civil Engineering, University of Belgrade, 1989. (unpublished).

[15] A. Rajčević, River Regulation seminar paper, Faculty of Civil Engineering, University of Belgrade, 1989. (unpublished).

[16] D. Prodanović, D. Pavlović and N. Branisavljević, Flow measurment in the short structures in hydraulic complex conditions - HE "Djerdap 2" case study (Merenje protoka na kratkim objektima $\mathrm{u}$ hidraulički neregularnim uslovima na primeru HE “Djerdap 2"), Vodoprivreda Vol. 43 No. 252-254, Belgrade, Serbia.

[17] I. Mitrović, Cooperation of Danube waterway administrations through Newada project (Saradnja dunavskih administracija za plovne puteve kroz projekat Newada), Vodoprivreda Vol. 43 No. 249-251, Belgrade, Serbia. 